\title{
Promoting Positive Behaviors Among the Lower Primary School Students
}

\author{
Kholood Fawaz Al-Zoby Prof. Mohammed Amin Al-Qudah
}

\begin{abstract}
The present study aimed to explore the role of family and school in promoting positive behaviors among the lower primary school students enrolled in the American Community School. It aimed to identify the methods of promoting positive behaviors among those students from the perspective of school principals, teachers, parents, and the lower primary school students. It was found that the (responsive classroom) approach is adopted by the American Community School for promoting positive behaviors among the lower primary school students. Adopting this approach enables teachers to create a positive environment in the whole school in general and classrooms in particular. It has a positive impact on students' academic achievement and self-discipline. It participates in delivering education of high quality. Based on the latter approach, it's very important to develop students' social-emotional skills. Such skills include: (taking responsibility, respecting others' opinions and selfconfidence). Based on the latter approach, it's very important to develop students' cognitive-academic skills and promote knowledge about the teaching methods. Based on the latter approach, cognitive development occurs through social interaction. This approach can be adopted for promoting positive behaviors among the lower primary school students. The researchers recommend adopting the (responsive classroom) approach for promoting positive behaviors among the lower primary school students. They recommend providing more attention to the provision of training courses for teachers and parents about the methods of promoting positive behaviors among the lower primary school students. They recommend conducting similar studies that target other school stages, such as: the secondary stage.
\end{abstract}

Keywords: Positive Behaviors, the Lower Primary School Students

DOI: $10.7176 / \mathrm{JEP} / 11-8-12$

Publication date:March $31^{\text {st }} 2020$

\section{Introduction:}

There are various social circumstances that affect one's personality. The impacts of social circumstances manifest through positive and negative behaviors. Education plays a very significant role in shaping one's behavior in a positive manner. Several social changes have been experienced by the world in general and the Arab World in particular. In the light of that, it has become very important to promote positive behaviors among people in general and children in particular. In fact, promotion positive behaviors plays a very significant role in developing society and achieving advancement.

Socialization can significantly affect the way in which people shall interact socially with others. That is because socialization develops children's personality in social areas and teaches them the prevalent values in society. I Socialization can promote positive behaviors among children. Through promoting positive behaviors among children, children shall be encouraged to do good deeds. They shall be encouraged to have internal control. They shall have acceptance to their culture and history (Ben Tarif\& Al-Qudah, 2019, Hatahet and Alqudah, Hamdan, 2015).

Family is the first one that practices socialization in one's life. It is a very important social unit in society. It instills values, traditions and attitudes within one. Having a defect in the society's families shall lead to having a defect in the whole society. Family raises up children who shall participate in developing the country in the future. The more effort the family exerts in raising up children, the healthier the society shall be (Al-Hailat et al., 2008; Al-Qudah, 2006, Al-Sharay'a, 2006).

Al-Tamimi\& A-Qudah (2019) and Al-Rashwan (2012) suggest that family is the most important social unit in society. They suggest that family plays a significant role in shaping one's behavior and personality. Parents instill the fundamental principles within one during childhood. Children are highly willing to adopt new values. Family gives child a name and provides him/her with information based on the experience of the family members. It provides one with culture, traditions, values, and social attitudes. It provides one with criteria to classify things into right and wrong. It informs one about his/her own duties and rights.

One imitates the behavior carried out by a parent or an adult family member surrounding him/her. Thus, a child adopts the values adopted by his/her family. Qamwah and Al-Qudah (2017) and Al-Naser (2004) suggest that educating children and instilling positive values within them have become difficult. That is attributed to the changes that have occurred to families. It is attributed to the increasing number of working mothers and technological developments. In the light of such changes, children today imitate the behavior of the ones that appear on television and social media channels in addition to imitating the behavior of family members. Thus, children today imitate the behaviors of several people in a direct or indirect manner. That shall lead to having 
behavioral problems. It shall make the children experience psychological instability because there are contradictions between the behaviors of the ones surrounding them and the behaviors of the ones appearing on social media or TV.

During the early school stage, the imitated behavior shall be carried out in school. School is responsible for instilling positive values within children and promoting positive behaviors among them. In fact, it is responsible for educating children. It is responsible for developing one in various areas, including the physical, cognitive, spiritual, religious, social and ethical areas. It plays a significant role in adjusting one's behavior (Al-Hammad and Al-Qudah, 2019, Malkawi and Al-Qudah, 2018, Al-Qudah, 2018; Hamandah and Al-Qudah, 2017, Thatha et al., 2012; Rashdan, 2005).

Negative behaviors have been widely spreading in contemporary societies. That is attributed to several economic and social circumstances. These circumstances changed the role of the family. They deprived families from warmth. They enforced several financial and psychological pressures on family members. They changed the priorities of family members. They led to assigning the responsibility of educating children to several people from various social and cultural backgrounds. They led to instilling negative values within children starting from an early age. They led to promoting negative behaviors among children.

It should be noted that schools play a significant role in promoting positive values and behaviors among children. Schools play a significant role in fighting against the negative behaviors that may be carried out by children. Children's behaviors are shaped through interacting with others in the school environment and being raised up by his/her family. Through carrying out positive behaviors, people participate in the development of society. Hence, the researchers of the present study believe that it is very important to explore and develop the behaviors carried out by lower primary school students. Developing children's behaviors shall participate in developing good citizens. Those citizens shall have much faith and belonging to their nation. They shall know their duties and rights and avoid committing deviant acts. They shall play an effective role in society and meeting their goals and ambitions in life.

\section{Statement of the Problem and the Study's Questions:}

Positive behavior has been receiving much attention by researchers. That is because positive behaviors play a significant role in shaping one's personality and determining one's goals. Positive behaviors enable societies to develop. Therefore, much attention must be devoted to the promotion of positive behaviors among school students. Such promotion must begin since early childhood till reaching secondary school stage.

One of the researchers of the present study has been teaching lower primary school students for about 20 years. She has been observing the behavior of those students in various schools that adopt international educational systems in Amman. When she started working a private school, she noticed that positive behaviors have been spreading among students. Such behaviors include: honesty, integrity, quietness, respect for teachers, and compliance with ethics \& the rules of morning assembly at school and etc.. The latter researcher also noticed that students have a strong, balanced, and leading personality. She noticed that students are in peace with themselves and others. She desire to know the reasons behind carrying out positive behaviors by the students enrolled in the American Community School. In the other schools that the researcher worked at, students have similar socioeconomic status and welfare level. However, they do not carry out positive behaviors.

Therefore, the present study aimed to explore the methods employed by school and family for promoting positive behaviors. To be specific, it aimed to answer the following questions:

Q.1: What is the role of the family and school in promoting positive behaviors among the lower primary school students from the perspective of school principals, teachers, parents, and the lower primary school students?

Q.2: What are the methods of promoting positive behaviors among the lower primary school students from the perspective of school principals, teachers, parents, and the lower primary school students?

\section{The Study's Objectives:}

The present study aimed to:

- Explore the role of the family and school in promoting positive behaviors among the lower primary school students from the perspective of school principals, teachers, parents, and the lower primary school students.

- Identify the methods of promoting positive behaviors among the lower primary school students from the perspective of school principals, teachers, parents, and the lower primary school students.

\section{The Study's Significance:}

The researchers of the present study conducted this study because they have much knowledge about the age category of the lower primary school students. They conducted this study because they realized that there are differences between the students of the American Community School and the students in other schools in terms of the extent of carrying out positive behaviors. They conducted this study because they believe that behavior is a very important issue that affect a whole generation. They conducted this study because the results of this study are 
very important and shall benefit the following categories:

\section{Educational institutions in the Hashemite Kingdom of Jordan:}

The present study shall guide those institutions in fighting violence and bullying behaviors among students. It shall guide those institutions in promoting positive behaviors among students. Such behaviors include: showing compliance with ethics and school rules. They include: being honest and showing respect for teachers. They include preserving the school properties, and being at peace with one's self and others. The present study shall guide those institutions in instilling internal control within students. Such internal control shall prevent the students from carrying out any negative behavior whether the teacher is present or absent.

The researchers who are interested in this area:

The present study provides those researchers with much knowledge about the study's subject. Such knowledge is related to the way of promoting positive behaviors among the lower primary school students.

The present study is significant because it shall fill a gap in the Arab literature in general and the Jordanian literature in particular in this subject. This subject is represented the promotion of positive behaviors among the lower primary school students.

It was necessary to conduct the present study because there aren't many studies in the Arab environment in general and the Jordanian environment in particular which aim to explore the relationship between family and school and identify the educational methods employed by family and school. In addition, there aren't many studies in the Arab environment in general and the Jordanian environment in particular which aim to identify the role of the educational methods in promoting positive behaviors among primary school stage. Thus, the present study shall assist researchers in conducting studies that aim at exploring the role of school and family in this regard and shedding a light on behavior and socialization.

\section{The operational definition of the study's terms:}

*Behavior: It refers to the way in which a being interacts with the surrounding environment. Most of one's behaviors is acquired from the people surrounding him/her. Behavior is acquired through observation, imitation, learning, training and practices. People learn simple and complex behaviors. The more the controlled the behavioral learning process is, the more effective this process shall be. When repeating a specific behavioral regularly, this behavior shall become a habit that is carried out in a spontaneous and easy manner.

*Positive behavior: It refers to expressing one's ideas, feelings, and opinions in a clear and direct manner without infringing others' rights, provided that others' feelings are taken into consideration.

Promoting positive behaviors: It refers to the process of instilling positive values and principles within student during an early academic stage.

*The lower primary school stage: It refers to the primary school stage that starts from $1^{\text {st }}$ grade and ends in $5^{\text {th }}$ grade.

\section{The Study's Limits:}

The present study was conducted during the academic year (2018/2019). It targets the lower primary school students in the American Community School.

\section{Previous Studies:}

Goldberg et al. (2019) aimed to explore the effectiveness of adopting a whole school approach for enhancing the social and emotional development ofchildren and young people. 45 studies were surveyed. These studies include 496,299 respondents. A meta-analysis was conducted. It was found that the whole school approach plays a significant positive role in enhancing the social and emotional development ofchildren and young people.

Al-Hantoushi and Al-E'taibi (2017) aimed to explore the family's contributions in raising up the future generations. The cluster random sampling method was used. The sample consists from 59 parents and 98 female and male students. It was found that family plays an effective role in raising up the future generation from the perspective of parents and students. It was found that there are differences between respondents' attitudes which are attributed to gender for the favor of males. It was found that there are differences between the parents' attitudes -in terms of skills and values- which are attributed to the academic qualifications. It was found that there isn't any difference between the parents' attitudes -in the cognitive areas- which are attributed to the academic qualifications.

Mbaluka (2017) aimed to explore the impact of students' self-discipline and parents' involvement in academic activities on students' academic performance. The sample consists from 5144 sixth and seventh grade students in Davidson School in North America. It was found that students' self-discipline significantly affect students' academic performance.

Abduh (2016) aimed to explore the extent of using punishment methods by the primary school teachers in the schools affiliated with Awqaf in Quds. He aimed to explore that from the perspective of those teachers. The sample consists from 650 teachers. It was found that the extent of using punishment methods by the primary school 
teachers in these schools is moderate. It was found that respondents have positive attitudes towards enforcing punishment on students.

Smithikraia (2016) aimed to explore the role of using movies in the teaching-learning process for promoting positive behaviors and characteristics. The sample consists from 156 undergraduate students who are enrolled at a public university in northern Thailand. A quasi-experimental approach was adopted. A questionnaire was used for data collection. It was found that using movies in the teaching-learning process play an effective role in promoting positive behaviors and characteristics. Thus, a systematic movie-based teaching strategy shall positively affect the way students behave.

Al-Madhoun (2016) aimed to explore the extent of carrying out positive behaviors by the students enrolled in Palestine University. He aimed to explore students' positive behaviors in accordance with gender and faculty. The sample consists from 247 students who are enrolled in Palestine University. It was found that there isn't any difference between students in terms of the extent of carrying out positive behaviors which can be attributed to gender.

Highberger (2015) conducted a study titled (A Study of Middle School Teacher Self-Efficacy and Student Discipline Rates). The sample consists from 58 teachers who work in a school in California, USA. Those teachers hold graduate certificates and have many years of experience. It was found that there is a significant relationship between the students' self- discipline and the teachers' self-efficacy.

Papker (2014) aimed to explore the effectiveness of using reward and punishment methods by school principals and teachers in Al-Qadarif, Sudan. He aimed to explore the attitudes of principals and teachers towards using these methods. The sample consists from 15 principals and 30 female and male teachers. Those principals and teachers were selected from several public schools. The stratified random sampling method was used. It was found that rewards motivate students to continue carrying out positive behaviors and using good words. It was found that rewards increase students' self-confidence levels and improve their capability to achieve.

Al-Za'er (2014) aimed to explore the relationship between upbringing and some prevalent behavioral disorders among the first grade students in primary schools in Al-Madrman, Sudan. The population consists from 270 students. A purposive sample was selected. It consists from 30 students; 15 males and 15 females. It was found that there is a correlation between the bad upbringing and some prevalent behavioral disorders among those students.

Alyan and Al-Nawajhah (2013) aimed to explore the effectiveness of a counseling program in developing some positive social behaviors among primary school students in Gaza. The members of the sample were divided into two groups; experimental and control groups. Each group consists from 20 th grade students. Regarding the students in the experimental group, it was found that there are statistically significant differences between their scores on the pre-test and their scores on the post-test. That means that the training measures in the counseling program play an effective role in developing students' positive social behaviors.

Carry School (2011) conducted a study for three years respectively. This study aimed to explore the effectiveness of the (responsive classroom) approach in raising academic achievement and improving the interaction between student and teacher. It aimed to explore the effectiveness of the latter approach in delivering education of high quality. The sample consists from 2900 primary school students. It was found that adopting the latter approach shall raise students' academic achievement and improve the interaction between student and teachers. It was found that adopting the latter approach shall provide education of high quality.

Al-Afandy (2011) aimed to explore the prevalent methods used for having discipline in secondary schools in Bait Lahem from the perspective of secondary school teachers and students. The sample consists from 175 teachers and 500 students. It was found that the prevalent methods are: the counseling, preventive, and therapeutic methods respectively. That was concluded the perspective of students and teachers.

Carry School (2010) conducted a study that aimed to explore the impact of the (the responsive classroom) approach on math teachers' practices. 88 third grade classrooms were sampled in 24 primary schools. However, it was found that adopting the latter approach reduces the pressures enforced on teachers and improves students' self-organization skills. It was found that adopting the latter approach facilitates the process of solving equations.

Horner and Sugai (2009) conducted a study titled (A Randomized, Wait-List Controlled Effectiveness Trial Assessing School-Wide Positive Behavior Support in Elementary School). They aimed to implement a program that aims at promoting positive behaviors among school students. This program has been implemented since experiencing an increase in the rates of criminalized and violent acts in schools. The latter researchers conducted the study in Hawaii and Illinois. A random sample was selected. It was found that there is a strong correlation between students' academic performance level and behavior. It was found that the behaviors of the students who are enrolled in the latter program improved.

Clark and Cooley (2007) conducted a study titled (Positive Behavior Support: A Case Study of the 4J and Bethel School Districts). A sample was selected from all the targeted areas. It was found that it is very important to promote positive behaviors among students. It was found that the extent of carrying out negative behaviors by respondents decreased. 
Eldridge and Barry (2003) conducted a study titled (Positive Behavior Support in Urban schools). They aimed to identify the capability to prevent the anti-social behavior. The sample was selected from a primary school in Lehigh, USA. It was found that refraining from enforcing punishment on students shall decrease the extent of experiencing behavioral problems. It was found that the anti-social behaviors can be prevented in urban schools. Fisher (2003) aimed to explore the extent of awareness among educational leaders about the ethical standards related to school administration and school management in New Orleans. The sample consists from 85 principals who hold $\mathrm{PhD}$ degree in educational administration. The latter study provides much knowledge about learning, honesty, optimism, and knowledge.

\section{Comments on the aforementioned studies:}

The aforementioned studies shed a light on several aspects that the present study aimed to explore. They enrich the framework of the present study and increase the reliability of the study's results. The present study is distinguish from the aforementioned studies. For instance, it aimed to explore the methods of promoting positive behaviors among students. It aimed to explore the role of family and school in promoting positive behaviors among students. As for the aforementioned studies, they do not shed a light on the latter methods and role.

The aforementioned studies do not shed a light on the significance of having cooperation between family and school in promoting positive behaviors among students. They do not shed a light on the significance of promoting positive behaviors. It should be noted that there is a scarcity in the studies that shed a light on promoting positive behaviors in the Arab World in general and Jordan in particular.

The present study is different from the aforementioned studies in terms of the spatial and temporal limits. It takes into consideration the changes that have occurred to societies. It sheds a light on the new upbringing methods. It sheds a light on the cooperation between school and family. It identifies the way of promoting, honesty, integrity, quietness, respect for teachers, and compliance with ethics \& the rules of morning assembly at school among students. Thus, it fills a gap in the relevant literature.

\section{Methods and procedures Methodology:}

The present study aimed to identify the methods of promoting positive behaviors among the lower primary school students. Thus, a qualitative approach was adopted and in-depth interviews were conducted. A descriptive analytical approach was adopted. This approach was adopted by many researchers for offering readers a sensory description for things and items. It can be adopted to determine whether certain sensory attributes are deemed accepted or not. It may be adopted by researchers to explore variables and their dimensions and constituents (Lawless and Heymann, 1999).

\section{Sample:}

The researchers selected a purposive sample from the American Community School in Amman, Jordan. They selected this school because they believe that this school plays an effective role in promoting positive values and behaviors among students. The sample consists from 5 lower primary school students, 6 parents and 6 teachers. It also consists from the general manager of the school and his deputy. It also consists from the lower primary school principal. It consists from the lower primary school vice-principal.

\section{Instrument:}

The researchers drafted a questions form. This form includes several open-ending questions for conducting interviews. They collected data through interviewing several lower primary school students, teachers, parents and principals about the methods of promoting positive behaviors among students.

\section{Validity:}

To measure the validity of the questions form, the form was passed to a panel of experts who are specialized in education and work at the University of Jordan. Those experts were asked to assess the form in terms of language, clarity and relevance. They were asked to make the necessary adjustments. The researchers decided to acknowledge the comments that are approved by $80 \%$ of the experts.

\section{Reliability:}

To measure the reliability of the questions form, the researchers selected an interview for a principal, an interview for a parent and an interview for a students. The answers of these interviewees were recorded in writing and analyzed. Such answers and their analysis were shown to those interviewees. Those interviewees approved the way of recording and writing their answers.

\section{Results and discussion related to the first question}


Q.1: What is the role of the family and school in promoting positive behaviors among the lower primary school students from the perspective of school principals, teachers, parents, and the lower primary school students?

To answer this question, the interviewees' answers in the interviews were analyzed. Frequencies and percentages were calculated.

First: Results from the perspective of the school principals and teachers:

The answers of teachers and principals in the interviews were analyzed. All those teachers and principals suggest that the (responsive classroom approach) plays a significant role in promoting positive behaviors and fighting against the negative behaviors.

Teachers and principals were asked to identify the role of the (responsive classroom approach) in promoting positive behaviors among students. The answers of the teachers and principals in the interviews are presented in table (1). Teachers and principals suggested that there are several reasons for students' refrainment from carrying out negative behaviors. Based on table (1), such reasons include: repeating the things expected from students in front of them and fighting against negative behaviors by teachers and principals in a pro-active manner. They include: spreading posters in all over the school. These posters include five things that students pledge to do. The latter reasons are approved by $100 \%$ of teachers and principals.

Such reasons include: carrying out intervention measures to address the negative behaviors instantly once the student commits them. They include: following up any case involving bullying. That is suggested by $83 \%$ of teachers and $25 \%$ of the principals. $50 \%$ of the principals use the word (pledges) instead of using the word (rules). That is because the word (pledge) makes students show commitment and compliance.

Table (1): The reasons of students' refrainment from violent and negative behaviors from the perspective of principals and teachers

\begin{tabular}{|c|c|c|c|c|c|}
\hline No. & $\begin{array}{l}\text { What are the reasons of students' refrainment } \\
\text { from violent and negative behaviors from the } \\
\text { perspective of principals and teachers? }\end{array}$ & $\begin{array}{l}\text { Frequency } \\
\text { among } \\
\text { principals }\end{array}$ & Percentage & $\begin{array}{l}\text { Frequency } \\
\text { among } \\
\text { teachers }\end{array}$ & Percentage \\
\hline 1. & $\begin{array}{l}\text { The things expected from students to do are } \\
\text { repeated in front of them. That is done based } \\
\text { on the (responsive classroom) approach. }\end{array}$ & 4 & $100 \%$ & 6 & $100 \%$ \\
\hline 2. & $\begin{array}{l}\text { Models of positive behaviors are presented in } \\
\text { front of students. That is done based on the } \\
\text { (responsive classroom) approach. }\end{array}$ & 3 & 75 & 6 & $100 \%$ \\
\hline 3. & $\begin{array}{l}\text { I comply with the principles of the } \\
\text { (responsive classroom) approach in order to } \\
\text { fight against the negative behaviors. We seek } \\
\text { adopting a pro-active approach to fight } \\
\text { against the negative behaviors. }\end{array}$ & 4 & $100 \%$ & 6 & $100 \%$ \\
\hline 4. & $\begin{array}{l}\text { There are posters in all over the school. These } \\
\text { posters include five pledges that students } \\
\text { pledged to do. Students are aware of these } \\
\text { pledges and memorize them and keep them. } \\
\text { That is done in accordance with the } \\
\text { (responsive classroom) approach. }\end{array}$ & 4 & $100 \%$ & 6 & $100 \%$ \\
\hline 5. & $\begin{array}{l}\text { I use the word (pledges) is used instead of } \\
\text { using the word (rules). That is because rules } \\
\text { may be violated. However, students do not } \\
\text { break their pledges }\end{array}$ & 2 & 50 & 0 & 0 \\
\hline 6. & $\begin{array}{l}\text { The relationship between students from one } \\
\text { hand and teachers and principals from another } \\
\text { hand is based on love, trust, respect. It is } \\
\text { based on the principles of the (responsive } \\
\text { classroom) approach. }\end{array}$ & 3 & 75 & 6 & 100 \\
\hline 7. & $\begin{array}{l}\text { The school starts following up the cases } \\
\text { involving bullying once they occur }\end{array}$ & 1 & 25 & 5 & 83.3 \\
\hline 8. & $\begin{array}{l}\text { The schools provides attention to students' } \\
\text { opinions. Students can express their feelings } \\
\text { whenever they desire. They are permitted to } \\
\text { do so in accordance with the principles of the } \\
\text { (responsive classroom) approach. }\end{array}$ & 2 & 50 & 6 & 100 \\
\hline
\end{tabular}




\begin{tabular}{|c|l|l|l|l|l|}
\hline No. & $\begin{array}{l}\text { What are the reasons of students' refrainment } \\
\text { from violent and negative behaviors from the } \\
\text { perspective of principals and teachers? }\end{array}$ & $\begin{array}{l}\text { Frequency } \\
\text { among } \\
\text { principals }\end{array}$ & Percentage & $\begin{array}{l}\text { Frequency } \\
\text { among } \\
\text { teachers }\end{array}$ & Percentage \\
\hline 9. & $\begin{array}{l}\text { Intervention measures are carried out to } \\
\text { address the negative behaviors instantly once } \\
\text { the student commits them }\end{array}$ & 1 & 5 & 83.3 \\
\hline 10. & $\begin{array}{l}\text { The language used by the teacher plays a } \\
\text { significant role in fighting against negative } \\
\text { behaviors }\end{array}$ & 2 & 50 & 6 & 100 \\
\hline
\end{tabular}

Based on table (2), analysis was conducted for the interviews conducted with teachers and principals at the American Community School. It was found that there is a special training provided for teachers about the way of promoting positive behaviors among students. There are in-depth training courses for teachers -at the beginning of each academic year- about the principles of the (responsive classroom) approach. On each Sunday, there are training courses given to teachers. Such courses include the following ones:

- A course titled: Promoting positive behaviors

- A course titled: The responsive classroom approach

- A course titled: Methods of addressing and adjusting the negative behavior

Some of the courses given on Sunday shed a light on academic issues. The answers of teachers and principals about training are presented in table (2). All of the things presented in table (2) are approved by $100 \%$ of principals and teachers.

Table (2): Do teachers receive special training about the way of promoting positive behaviors among students at the beginning of each year?

\begin{tabular}{|l|l|l|l|l|l|}
\hline No. & $\begin{array}{l}\text { Do teachers receive special training about the way } \\
\text { of promoting positive behaviors among students } \\
\text { at the beginning of each year? }\end{array}$ & $\begin{array}{l}\text { Frequency } \\
\text { among } \\
\text { principals }\end{array}$ & Percentage & $\begin{array}{l}\text { Frequency } \\
\text { among } \\
\text { teachers }\end{array}$ & Percentage \\
\hline 1. & $\begin{array}{l}\text { Teachers are provided with in-depth training at } \\
\text { the beginning of the academic year }\end{array}$ & 4 & $100 \%$ & 6 & $100 \%$ \\
\hline 2. & $\begin{array}{l}\text { Many of these courses shed a light on the } \\
\text { principles of the (responsive classroom) } \\
\text { approach. }\end{array}$ & $\begin{array}{l}\text { On each Sunday, there are training courses given } \\
\text { to teachers. Such courses include the following } \\
\text { ones: } \\
-\quad \begin{array}{l}\text { A course titled: Promoting positive } \\
\text { behaviors } \\
\text { A course titled: The responsive classroom } \\
\text { approach } \\
\text { A course titled: Methods of addressing and } \\
\text { adjusting the negative behavior }\end{array} \\
\begin{array}{l}\text { Some of the courses given on Sunday shed a light } \\
\text { on academic issues. }\end{array}\end{array}$ & & $100 \%$ & 6 \\
\hline
\end{tabular}

Based on table (3), it was found that the conversation is one of the methods used by principals and teachers for adjusting the negative behaviors committed by students. Through having a conversation with the student, principals and teachers shall identify the reasons of committing the negative behavior and the method of making a behavioral adjustment. This conversation must be consistent with the principles of the responsive classroom approach. The methods of adjusting the negative behaviors include: enforcing logical suitable punishment that fits with the seriousness of the committed negative behavior. $100 \%$ of the teachers and principals suggest that.

Based on the interviews conducted with the principals and teachers, there are several methods for adjusting the negative behavior. Such methods include: developing the relationship with the student and identifying his/her interests, inclinations, and hobbies. They include gaining knowledge from the books that address the responsive classroom approach. Such books include information about the logical punishment and the way of addressing the negative behavior. $88.3 \%$ of the teachers suggest that. $75 \%$ of the principals suggest that

Table (3) presents the methods of adjusting the negative behaviors. Such methods include: holding a meeting to propose suitable solutions for addressing the negative behavior committed by students. This meeting must be attended by the principal, vice-principal, counselor, and teacher. $83 \%$ of the teachers suggest that and $75 \%$ of principals suggest that. 
Table (3): Methods for adjusting the negative behaviors committed by students

\begin{tabular}{|c|c|c|c|c|c|}
\hline No. & Methods & $\begin{array}{l}\text { Frequency } \\
\text { among } \\
\text { principals }\end{array}$ & Percentage & $\begin{array}{l}\text { Frequency } \\
\text { among } \\
\text { teachers }\end{array}$ & Percentage \\
\hline 1. & $\begin{array}{l}\text { Such methods include developing the relationship } \\
\text { with the student and identifying his/her interests, } \\
\text { inclinations, and hobbies. }\end{array}$ & 3 & 75 & 5 & 83.3 \\
\hline 2. & $\begin{array}{l}\text { Such methods include having a conversation with } \\
\text { the students. Through having a conversation, } \\
\text { principals and teachers can identify the reasons of } \\
\text { committing the behavior and the way of making a } \\
\text { behavioral adjustment. } \\
\text { This conversation must be consistent with the } \\
\text { principles of the responsive classroom approach }\end{array}$ & 4 & 100 & 6 & 100 \\
\hline 3. & $\begin{array}{l}\text { Such methods include enforcing logical suitable } \\
\text { punishment that fits with the seriousness of the } \\
\text { committed negative behavior }\end{array}$ & 4 & 100 & 6 & 100 \\
\hline 4. & $\begin{array}{l}\text { Such methods include holding a meeting to } \\
\text { propose suitable solutions for addressing the } \\
\text { negative behavior committed by students. This } \\
\text { meeting must be attended by the principal, vice- } \\
\text { principal, counselor, and teacher. }\end{array}$ & 4 & 100 & 5 & 83.3 \\
\hline 5. & $\begin{array}{l}\text { Such methods include gaining knowledge from the } \\
\text { books that address the responsive classroom } \\
\text { approach. Such books include information about } \\
\text { the logical punishment and the way of addressing } \\
\text { the negative behavior }\end{array}$ & 3 & 75 & 5 & 83.3 \\
\hline
\end{tabular}

Based on table (4), the sampled teachers and principals do not use stickers nor the incentive boards to motivate students to carry out positive behaviors. They seek raising students' self-satisfaction about themselves when doing positive behaviors. They teach students that it's not important what others feel towards one. In fact, they teach students that what matters is what one feels towards his/her behaviors. They motivate students to carry out positive behaviors through mentioning the good behavior they did in front of others and praising the students for doing the good behavior. $100 \%$ of the principals and teachers suggest that.

Table (4): When the student carries out a positive behavior, are there stimuli that motivate him/her to continue carrying out the positive behavior?

\begin{tabular}{|l|l|l|l|l|l|}
\hline No. & $\begin{array}{l}\text { When the student carries out a positive behavior, } \\
\text { are there stimuli that motivate him/her to continue } \\
\text { carrying out the positive behavior? }\end{array}$ & $\begin{array}{l}\text { Frequency } \\
\text { among } \\
\text { principals }\end{array}$ & Percentage & $\begin{array}{l}\text { Frequency } \\
\text { among } \\
\text { teachers }\end{array}$ & Percentage \\
\hline 1. & $\begin{array}{l}\text { I do not use stickers nor the incentive boards to } \\
\text { motivate students to carry out positive behaviors }\end{array}$ & 4 & 100 & 6 & 100 \\
\hline 2. & $\begin{array}{l}\text { I seek raising students self-satisfaction about } \\
\text { themselves when doing positive behaviors. }\end{array}$ & 4 & 100 & 6 & 100 \\
\hline 3. & $\begin{array}{l}\text { I teach students that it's not important what others } \\
\text { feel towards one. In fact, I teach students that } \\
\text { what matters is what one feels towards his/her } \\
\text { own behaviors }\end{array}$ & 4 & 100 & 6 & 100 \\
\hline 4. & $\begin{array}{l}\text { I motivate students to carry out positive behaviors } \\
\text { through mentioning the good behavior they did in } \\
\text { front of others and praising the students for doing } \\
\text { the good behavior }\end{array}$ & 4 & 100 & 6 & 100 \\
\hline
\end{tabular}

Based on table (5), the types of guidance provided to the student in case he/she carried out a negative behavior include having a conversation with the student. They include: making the student feel that one is always there to support him/her. They include: providing the student with daily training about the way he/she ought to behave and the language he/she ought to use. They include: exerting effort by the school counselor to adjust the student's behavior. These types were suggested by $100 \%$ of the principals and teachers. 
Table (5): The types of guidance provided to the student in case he/she carried out a negative behavior

\begin{tabular}{|l|l|l|l|l|l|}
\hline No. & $\begin{array}{l}\text { The types of guidance provided to the student in } \\
\text { case he/she carried out a negative behavior }\end{array}$ & $\begin{array}{l}\text { Frequency } \\
\text { among } \\
\text { principals }\end{array}$ & Percentage & $\begin{array}{l}\text { Frequency } \\
\text { among } \\
\text { teachers }\end{array}$ & Percentage \\
\hline 1. & $\begin{array}{l}\text { Guidance is provided to the student through } \\
\text { having a conversation with him/her }\end{array}$ & 4 & $100 \%$ & 6 & $100 \%$ \\
\hline 2. & $\begin{array}{l}\text { I make the student feel that I am always there to } \\
\text { support him/her }\end{array}$ & 4 & $100 \%$ & 6 & $100 \%$ \\
\hline 3. & $\begin{array}{l}\text { The student is provided with daily training about } \\
\text { the way he/she ought to behave and the language } \\
\text { he/she ought to use }\end{array}$ & 4 & $100 \%$ & 6 & $100 \%$ \\
\hline 4. & $\begin{array}{l}\text { The school counselor exerts effort in adjusting } \\
\text { the student's behavior }\end{array}$ & 4 & $100 \%$ & 6 & $100 \%$ \\
\hline
\end{tabular}

\section{Second: Results from the perspective of parents}

The researcher analyzed the answers of the parents of the lower primary school students in the American Community School.

Based on table (6), there are several types of guidance provided by the parent to the child in case he/she carried out a negative behavior. Such types include: having a conversation with the child. Through this conversation, the parent asks the child about the reasons behind his/her anger and the motives of carrying out the behavior. Through having such a conversation, the parent asks the child about his/her feelings while carrying out the behavior. The sampled parents refrain from using violence in case the child carried out a negative behavior. That was suggested by $100 \%$ of the parents.

Such types of guidance include: depriving the child from advantages that were given to him/her. That was suggested by $83.3 \%$ of the parents. Such types include reminding the child about the implications of his/her behavior, in case he/she repeated it. That was suggested by $100 \%$ of the parents.

Table (6): The types of guidance provided by the parent to the student in case he/she carried out a negative behavior

\begin{tabular}{|l|l|l|l|}
\hline No. & $\begin{array}{l}\text { The types of guidance provided by the parent to the student in case } \\
\text { he/she carried out a negative behavior }\end{array}$ & $\begin{array}{l}\text { Frequency } \\
\text { among } \\
\text { parent }\end{array}$ & Percentage \\
\hline 1. & $\begin{array}{l}\text { Guidance is provide through having a conversation with my child. } \\
\text { Through having such a conversation, I ask my child about the reasons } \\
\text { behind his/her anger and the motives of carrying out the behavior. I ask } \\
\text { my child about his/her feelings while carrying out the behavior }\end{array}$ & 6 & 100 \\
\hline 2. & I may deprive my child from advantages that were given to him/her & 5 & 83.3 \\
\hline 3. & $\begin{array}{l}\text { I always remind my child about the implications of his/her behavior, in } \\
\text { case he/she repeated it }\end{array}$ & 4 & 66.6 \\
\hline 4. & $\begin{array}{l}\text { I don't use physical violence with my child, when he/she carries out a } \\
\text { negative behavior }\end{array}$ & 6 & 100 \\
\hline
\end{tabular}

Based on table (7), when the child carries out a positive behavior, there are stimuli provided by the parents for motivating the child to continue carrying out the positive behavior. Such stimuli include: praising the child and telling him/her that the parent is proud of him/her. In addition, the parents refrain from creating a connection between carrying out the good behavior and giving rewards. Such stimuli include: asking the child about his/her feelings when carrying out a positive behavior. They include telling the child that this feeling is the best feeling in the world. They include mentioning the child's positive behavior and praising him/her in front of others. Those stimuli are suggested by $100 \%$ of the parents.

Table (7): When the child carries out a positive behavior, are there stimuli that motivate him/her to continue carrying out the positive behavior?

\begin{tabular}{|l|l|l|l|}
\hline No. & $\begin{array}{l}\text { When the child carries out a positive behavior, are there stimuli that motivate } \\
\text { him/her to continue carrying out the positive behavior? }\end{array}$ & $\begin{array}{l}\text { Frequency } \\
\text { among } \\
\text { parent }\end{array}$ & Percentage \\
\hline 1. & I always praise my child and tells him/her that I am proud of him/her & 6 & $100 \%$ \\
\hline 2. & $\begin{array}{l}\text { I don't create a connection between carrying out the good behavior and giving } \\
\text { rewards. That is because I don't want my child to do the good behavior just } \\
\text { for receiving a reward. }\end{array}$ & 6 & $100 \%$ \\
\hline 3. & $\begin{array}{l}\text { I always ask my child about his/her feelings when carrying out a positive } \\
\text { behavior. I always tell him that this the feeling is the best feeling in the world }\end{array}$ & 6 & $100 \%$ \\
\hline 4. & I mention my child's positive behavior and praising him/her in front of others & 6 & $100 \%$ \\
\hline
\end{tabular}


Based on table (8), parents are always provided with training courses about the way of dealing with child, and the rules \& regulations of the school. The school always develops plans for adjusting the child's behavior. It follows up the child after he/she commits a negative behavior. It provides much attention to the child's feelings. These things were suggested by $100 \%$ of parents.

Table (8): Do parents receive special training about their children's behavior at school and the rules and regulations of the school?

\begin{tabular}{|l|l|l|l|}
\hline No. & $\begin{array}{l}\text { Do parents receive special training about their children's behavior at } \\
\text { school and the rules and regulations of the school? }\end{array}$ & $\begin{array}{l}\text { Frequency } \\
\text { among parent }\end{array}$ & Percentage \\
\hline 1. & $\begin{array}{l}\text { Yes, I am always provided with training courses about the way of } \\
\text { dealing with my child, and the rules and regulations of the school }\end{array}$ & 6 & $100 \%$ \\
\hline 2. & The school always develops plans for adjusting my child's behavior & 6 & $100 \%$ \\
\hline 3. & $\begin{array}{l}\text { The school follows up my child after he/she commits a negative } \\
\text { behavior. It provides much attention to my child's feelings }\end{array}$ & 6 & $100 \%$ \\
\hline
\end{tabular}

Third: Results from the perspective of the lower primary school students:

Based on table (9), it was found that the teacher tells the students about the things she expects from them. The teacher also informs the students about the significance of meeting these expectations. The students receive training about the way of meeting these expectations. It was found that the students have made special pledges in their classroom. The students set those pledges with the help of their teacher. There are posters in the classroom that include these pledges. Those posters are placed on the wall of the classroom. It was found that the teacher always remind the students about the pledges that they have made and the things she expects from them to do. It was found that such expectations include: raising finger before talking and showing respect to the teacher. Such expectations include: refraining from interrupting others while talking. They include: showing compliance with the rules of morning assembly at school. They include: making the right choice and handling responsibility for their own choices. These things were suggested by $100 \%$ of students.

Table (9): Are the students informed about the policies and rules of the school? If yes, how does that occur?

\begin{tabular}{|l|l|l|l|}
\hline No. & $\begin{array}{l}\text { Are the students informed about the policies and rules of the school? If yes, } \\
\text { how does that occur? }\end{array}$ & $\begin{array}{l}\text { Frequency } \\
\text { among } \\
\text { students }\end{array}$ & Percentage \\
\hline 1. & $\begin{array}{l}\text { Yes, on the first day of school, the teacher tells us about the things she } \\
\text { expects from us. The teacher also informs us about the significance of } \\
\text { meeting these expectations. We received training about the way of meeting } \\
\text { these expectations. }\end{array}$ & 5 & $100 \%$ \\
\hline 2. & $\begin{array}{l}\text { We have made special pledges in our classroom. We set those pledges with } \\
\text { the help of our teacher. There are posters in the classroom that include } \\
\text { these pledges. Those posters are placed on the wall of the classroom }\end{array}$ & $100 \%$ \\
\hline 3. & $\begin{array}{l}\text { The teacher always reminds us about the pledges we have made and the } \\
\text { things she expects from us to do }\end{array}$ & 5 & $100 \%$ \\
\hline 4. & $\begin{array}{l}\text { Such expectations include: raising finger before talking and showing } \\
\text { respect to the teacher. They include: refraining from interrupting others } \\
\text { while talking. They include: showing compliance with rules of morning } \\
\text { assembly at school. They include: making the right choice and handling } \\
\text { responsibility for our own choices }\end{array}$ & 5 & $100 \%$ \\
\hline
\end{tabular}

Based on table (10), in case a student re-committed the negative behavior, the teacher shall contact the students' parents. Furthermore, when any student commits a negative behavior, the teacher reminds the students about the positive behavior that ought to be committed. None of the students shall be informed about the negative behavior committed by the student. These things were suggested by $100 \%$ of students.

Table (10): What are the types of guidance provided by the school to the student in case he/she carried out a negative behavior?

\begin{tabular}{|r|l|l|l|}
\hline No. & $\begin{array}{l}\text { What are the types of guidance provided by the school to the student in } \\
\text { case he/she carried out a negative behavior? }\end{array}$ & $\begin{array}{l}\text { Frequency } \\
\text { among } \\
\text { students }\end{array}$ & Percentage \\
\hline 1. & $\begin{array}{l}\text { When any student commits a negative behavior, the teacher reminds us } \\
\text { about the positive behavior that ought to be committed. None of the } \\
\text { students shall be informed about the negative behavior committed by } \\
\text { the student }\end{array}$ & 5 & 100 \\
\hline 2. & $\begin{array}{l}\text { In case a student re-committed the negative behavior, the teacher } \\
\text { contacts the students' parents }\end{array}$ & 5 & 100 \\
\hline
\end{tabular}

Table (11) presents the reasons of students' refrainment from violent and negative behaviors from the 
perspective of students. Such reasons include: having better solutions for making people listen to them. That is suggested by $60 \%$ of the students. Such reasons include: avoiding causing problems for one's self. It was found that students don't like causing problems for themselves. It was found that committing a negative behavior shall make the students hate themselves. It was found that students don't like disappointing people. These things were suggested by $100 \%$ of students. It was found that students don't use violence, because they are aware of the positive behavior they ought to commit. That was suggested by $80 \%$ of students.

Table (11): The reasons of students' refrainment from violent and negative behaviors from the perspective of students

\begin{tabular}{|r|l|l|l|}
\hline No. & $\begin{array}{l}\text { The reasons of students' refrainment from violent and negative } \\
\text { behaviors from the perspective of students }\end{array}$ & $\begin{array}{l}\text { Frequency } \\
\text { among } \\
\text { students }\end{array}$ & Percentage \\
\hline 1. & There are always better solutions for making people listen to me & 3 & 60 \\
\hline 2. & I don't like causing problems for myself & 5 & 100 \\
\hline 3. & Committing a negative behavior shall make me hate myself & 5 & 100 \\
\hline 4. & I don't like disappointing people & 5 & 100 \\
\hline 5. & $\begin{array}{l}\text { I don't use violence. That is because I am aware of the positive behavior } \\
\text { I ought to commit }\end{array}$ & 4 & 80 \\
\hline
\end{tabular}

Through analyzing the interviews conducted with the principals, teachers, parents and students, it was found that the respondents share similar opinions about the methods used for promoting positive behaviors among the lower primary school students in the American Community School. These methods are based on the responsive classroom approach. They aim at creating safe and controlled environment. They aim at promoting self-discipline, and compliance with ethics. They aim at developing students' skills and behaviors inside the classroom. These skills and behaviors shall enable students to develop society. The latter methods shall enable many primary school teachers to ensure quietness and safety in classrooms. They shall develop students' self-discipline and sense of responsibility. Based on the responsive classroom approach, discipline can be taught just like reading, writing and math.

The latter results are consistent with the results concluded by Papker (2014), Clark and Cooley (2007) and Eldridge, and Barry (2003). For instance, Papker (2014) suggests that rewards motivate students to continue doing positive behaviors and using good words. He suggests that rewards increase students' self-confidence and improve their capability to achieve. As for Eldridge, and Barry (2003), they suggest that refraining from enforcing punishment on students shall lead to a decrease in the extent of experiencing behavioral problems. It was found that the anti-social behaviors can be prevented in urban schools.

The latter results are consistent with the results concluded by the studies of Carry School $(2010,2011)$. For instance, the study of Carry School (2011) suggests that adopting the (responsive classroom) approach shall raise students' academic achievement and improve the interaction between student and teachers. It suggests that adopting the (responsive classroom) approach shall provide education of high quality. The study of Carry School (2010) suggests that adopting the (responsive classroom) approach reduces the pressures enforced on teachers and improves students' self-organization skills. It suggests that adopting this approach shall facilitate the process of solving equations.

\section{Results and discussion related to the second question}

Q.2: What are the methods of promoting positive behaviors among the lower primary school students from the perspective of school principals, teachers, parents, and the lower primary school students?

Through analyzing interviews, it was found that the (Responsive classroom approach) plays a significant role in promoting positive behaviors among students. For instance, based on this approach, discipline can be taught just like reading, writing and math. Based on this approach, certain skills of students must be developed to become successful in social and academic areas inside and outside the school. Based on this approach, the student must be actively engaged in the teaching-learning process. He/she must a good listener who loves adventures and utilizes opportunities. He/she must show respect to others' opinions and ask questions during class.

Based on the latter approach, it's very important to develop students' social-emotional skills. Such skills include: (taking responsibility, respecting others' opinions and self-confidence). Based on the latter approach, it's very important to develop students' cognitive-academic skills and promote knowledge about the teaching methods. Based on the latter approach, cognitive development occurs through social interaction.

The (responsive classroom) approach is an approach not a program. The educational program must be implemented with following all the steps in it. Additions and deletions can't be made to such steps. However, the educational approach is considered more flexible than the educational program. It can be adopted in a manner that meets one's needs. It can be adjusted in accordance with the required requirements and circumstances.

The (responsive classroom) approach effective. That's because it can adopted in a manner that suits the educational context. 
The (responsive classroom) approach aims at creating an educational environment that is based on quietness, order, and safety. It aims at developing students' self-discipline, and self-control, and make them handle responsibility and contribute effectively in a democratic society. It aims at promoting values of respect and kindness. It aims at promoting healthy teacher-student and student-student interaction inside the classroom (Brady et al., 2003).

Based on the latter approach, it's necessary to develop students' social- emotional skills before developing their academic skills. Based on the latter approach, it's necessary to inform students about the things expected from them to do. It's necessary to present models of positive behavior in front of them. That shall facilitate the process of understanding these behaviors. It shall make students' aware of the way they ought to behave.

The (responsive classroom) approach is an educational approach that aims at raising students' academic achievement and improving the school climate. It aims at raising teachers' efficiency. It was proposed in 1991 by several teachers who work in public schools located in Massachusetts, USA. Those teachers share a similar vision. They also believe that social and academic learning must be practiced in the same school day. This approach aims at developing several academic, social and emotional skills. These skills can be developed through school programs (Wood and Loftis, 2011).

The latter results are consistent with the results concluded by the studies of Carry School (2010, 2011). For instance, the study of Carry School (2011) suggests that adopting the (responsive classroom) approach shall raise students' academic achievement and improve the interaction between student and teachers. It suggests that adopting the (responsive classroom) approach shall provide education of high quality. The study of Carry School (2010) suggests that adopting the (responsive classroom) approach reduces the pressures enforced on teachers and improves students' self-organization skills. It suggests that adopting this approach shall facilitate the process of solving equations.

\section{Conclusion:}

The following results were concluded:

- The family and school play an effective role in promoting positive behaviors among the lower primary school students.

- The responsive classroom approach is effective for promoting positive behaviors among the lower primary school students.

- $\quad$ There are various methods for promoting positive behaviors among the lower primary school students. Such methods include: making students take pledges.

In the light of these results, it can be concluded that family and school play a very important role in shaping the behaviors of students. Therefore, policies must be developed for activating the role of family and school in shaping students' behaviors. In the light of these results, the management of schools must provide more attention to the responsive classroom approach

\section{Recommendations and suggestions:}

The researchers recommend:

Adopting the (responsive classroom) approach in schools to promote positive behaviors among students providing more attention to the provision of training courses for teachers and parents about the methods of promoting positive behaviors among the lower primary school students

- $\quad$ Conducting more similar studies that target students in other school stages, such as: the secondary stage.

\section{References:}

- Papker, Mohammad (2014). The effectiveness of using reward and punishment methods by the school administration and attitudes towards them. Published MA thesis. Gadarif University. Sudan

- Hamdan, Mohammad (2015). Developing a classification for the social behavior, coexistence, adjustment, appreciation, commitment, collaboration and integration. $1^{\text {st }}$ edition. Syria. Al-Tarbeye AlHadeethe. Publication and Distribution House.

- Al-Hantoushi, Bader and Al-E'taibi, Abdullah (2017). The role of the family in promoting educational role to build future generations. The International Educational Journal. 6(6). 45-55.

- $\quad$ Rashwan, Hussein (2012). Socialization: A study in the field of Social psychology. $1^{\text {st }}$ edition. Alexandria. Alwafa' le Dunya Publication and Distribution House.

- Al-Rashwan, Abdullah. (2005). Education and socialization. $1^{\text {st }}$ edition. Amman. Wa'el publication and distribution house.

- Al-Za'er, Abdullah (2014). The bad upbringing and its relationship with some behavioral disorders of first grade students: A descriptive study in the local primary schools in Al-Madrman. Published MA thesis. Sudan University of Science and Technology. Khartoom, Sudan 
- Al-Sharay’a, Mohammad (2006). Socialization. $1^{\text {st }}$ edition. Amman. Yafa Alelmeye publication and distribution house.

- Abduh, Sereen (2016). The extent of using punishment methods by the primary school teachers in the schools affiliated with Awqaf in Quds and the attitudes of those teachers towards these methods. Published MA thesis. An-Najah National University. Nables. Palestine.

- Alyan, Mohammad and Al-Nawajhah, Zuhair (2013). The effectiveness of a counseling program in developing some positive social behaviors among primary school students in Gaza. Open Quds University Journal for Educational and Psychological Research 2(5). 397-417.

- Al-Afandy, Isma'il (2011). The prevalent methods used for having discipline in the secondary schools in Bait Lahem from the perspective of secondary school teachers and students. Published MA thesis. Open Quds University. Bait Lahem. Palestine.

- Al-Madhoun, Abed Al-Kareem (2016). Positive behaviors and their relationship with some variables among the students enrolled in Palestine University in Gaza. Open Quds University Journal for Educational and Psychological Research 6(19). 118-239.

- $\quad$ Naser, Ibrahim. (2014). Socialization. 1st edition. Amman. Ammar publication and distribution house.

- Responsive classroom (2016). What the research says. Retrieved from www.responsive classroom.Org.

- Ottmar, E. R., Rimm-Kaufman, S, E, Berry, R. Q. \& Larsen, R. A. (2013). Does the Responsive Classroom Approach affect the use of Standards-Based Mathematics teaching practices? Results from a randomized controlled trial. The Elementary School Journal, 113(3), 434-457.

- Al-Hammad, A \& Al-Qudah, M. (2019). Role of Jordanian Universities in Educating Students on Entrepreneurship from the Point of View of Juggling Students, An Interdisciplinary Journal for Science and Technology Studies, 13(1): 167-180

- Al-Tamimi, A \& Al-Qudah, M.A (2019) The Relationship between the parenting Styles of the Students of the First Three Grades with their Level of Creativity, An Interdisciplinary Journal for Science and technology Studies, (13)01: 123-134.

- Al-Qudah, M (2006). The Relationship between Family Socialization Patterns and Some Personality Attributes of Female Undergraduates at Mu'tah University, Jordan Journal of Educational Sciences, 2(3): 155-168.

- Al-Qudah, M (2017). The Extent University of Jordan Students Represent Islamic Values from Their Perspective, Dirasat: Educational Sciences,44(4), 9: 257-275.

- $\quad$ Ben Tarif, E \& Al-Qudah, M. (2019). International Journal of Advanced Science and Technology The Reality about the Educational Capabilities of the Jordanian Women in preventing their Sons / Daughters from Adopting Fanatical Ideologies, Journal of Advanced Science 13(4):214-227

- Brady, Kathryn and Forton, Mary and Porter, Deborah (2003), Rules in school, .Northeast Foundation for children, Inc.

- Clark, A and Cooley, Z (2007), Positive Behavior Support: A Case Study of the 4J and Bethel School Districts, Undergraduate Students at the Department of Economics, University of Oregon Advisor: Professor Bruce Blonigen.

- $\quad$ Eldridge, N and Barry, M (2003), Positive Behavior Support in Urban Schools, journal of positive behavior interventions, (3)5,158-170.

- Fisher, J (2003), Signal Expression in Tissues, Rice University, London, UK. Hatahet. F \&Alquda, M. (2016). Family Problems Experienced by Students of the University of Jordan, European Scientific Journal (12)13: $145-156$

- Hammadneh, O \& Al-Qudah. (2017). A Proposed Educational Role to The Jordanian Public Universities to Improve Their Students' Values, Dirasat: Educational Sciences, (44)4, 1: 185-203.

- Heilat, M \& Al-Qudah, M\&\& AL-Rbabaah, J. (2008) The relationship between family socialization patterns and emotional disturbance among 6th grade male students ,Association of Arab Universities Journal for Education and Psychology, 1(6): 1-34. Highberger, Allison (2015). A Study of Middle School Teacher Self-Efficacy and Student..Discipline. Rates (ProQuest Dissertations Publishing). Retrieved from http://search.proquest.com/docview/1780133304

- Horner, R and Sugai,G (2009)A Randomized, Wait-List Controlled Effectiveness Trial Assessing SchoolWide Positive Behavior Support in Elementary School, journal of positive behavior interventions,(3)11,133-144.

- $\quad$ Malkawi, S \& Al-Qudah, M. (2018, 1). Reality and Obstacles of the Partnership between Family and School in Jordan, Modern Applied Science, 2(12), 81-92.

- Malkawi, S \& Al-Qudah, M. (2018, 2). The Reality of Partnership Between The Family and The School from The Perspective of Teachers' Working in Irbid First Education Directorate, Dirasat: Educational Sciences, 45(3): 209-225. 
- Mbaluka, Susan (2017). The Impact of Student Self-Discipline and Parental Involvement in Students' Academic Activities on Student Academic Performance (ProQuest Dissertations Publishing). Retrieved from http://search.proquest.com/docview/2030111052/

- $\quad$ Qamweh, M \& Al-Qudah, M (2017) A Proposed Educational Guide to Help Working 25 Woman to Match between Works and Raising Children, Dirasat: Educational Sciences, (44)4, 6: 109-139.

- Zaza, H \&Heilat, M \& Al-Qudah, M. (2012). The acquisition and practicing degree of ministry of education teachers in Jordan for instruction strategies and evaluation based knowledge economy, Journal of King Saud university: Education science \& Islamic studies, (24)3: 619-652. IJETMR Banner

- Wood, Chip \& Loftis, Babs (2011), Responsive School Discipline, Northeast. Foundation for children, Inc.

- $\quad$ AL-Qudah, M. and Fallouh, R. (2020). The Capability to Predict the Behaviors of the Students Enrolled in Jordanian Universities Through Their Aesthetic Values. The Journal of Education and Practice.11(4).DOI: $10.7176 / \mathrm{JEP} / 11-4-11$

- Lawless H., and Heymann H. (1999) Descriptive Analysis. In: Sensory Evaluation of Food. Food science text series. Springer, Boston, MA

- Smithikraia, C. (2016). Effectiveness of Teaching with Movies to Promote Positive Characteristics and Behaviors. future Academy's Multidisciplinary Conference

- $\quad$ Goldberg, J.M., Sklad, M., Elfrink, T.R. (2019). Effectiveness of interventions adopting a whole school approach to enhancing social and emotional development: a meta-analysis. Eur J PsycholEduc 34, 755-782 https://doi.org/10.1007/s10212-018-0406-9

Acknowledgement:

The researchers of this study would like to thank the respondents who participated in the present study. 